WSRC-TR-98-00238

\title{
Tritium Permeation Estimate from APT and CLWR-TEF Waste Packages (U)
}

\author{
Elliot A. Clark
}

Savannah River Technology Center

Strategic Materials Technology Department

Materials Technology Section

Publication Date: July 31, 1998

\section{Westinghouse Savannah River Company Savannah River Site Aiken, South Carolina}

This document was prepared in connection with work done under Contract No. DE-AC09-96SR18500 with the U.S. Department of Energy. By acceptance of this document, the publisher and/or recipient acknowledges the U.S. Government's right to retain a nonexclusive, royalty-free license in and to any copyright covering this document, along with the right to reproduce and authorize others to reproduce all or part of the copyrighted material. 


\section{DISCLAIMER}

This report was prepared as an account of work sponsored by an agency of the United States Government. Neither the United States Government nor any agency thereof, nor any of their employees, makes any warranty, express or implied, or assumes any legal liability or responsibility for the accuracy, completeness, or usefulness of any information, apparatus, product, or process disclosed, or represents that its use would not infringe privately owned rights. Reference herein to any specific commercial product, process, or service by trade name, trademark, manufacturer, or otherwise does not necessarily constitute or imply its endorsement, recommendation, or favoring by the United States Government or any agency thereof. The views and opinions of authors expressed herein do not necessarily state or reflect those of the United States Government or any agency thereof.

This report has been reproduced directly from the best available copy.

Available to DOE and DOE contractors from the Office of Scientific and Technical Information, P.O. Box 62, Oak Ridge, TN 37831; prices available from (615) 576-8401.

Available to the public from the National Technical Information Service, U.S. Department of Commerce; 5285 Port Royal Road, Springfield, VA 22161. 


\section{DISCLAIMER}

Portions of this document may be illegible in electronic image products. Images are produced from the best available original document. 


\title{
SMTD
}

STRATEGIC MATERIALS TECHNOLOGY DEPARTMENT

Keywords: Tritium, Low Level Waste Disposal

Retention - Permanent

\section{Tritium Permeation Estimate from APT and CLWR - TEF Waste Packages (U)}

by

\author{
Elliot A. Clark
}

DOES NOT CONTAIN

UNCLASSIFIED CONTROLLED

NUCLEAR INFORMATION
ADC \&
Reviewing 7. Themes 0 . 0 .
Date: August 10,1998
SRTC SAVANNAH RIVER TECHNOLOGY CENTER, AIKEN, SC 29808

\section{Westinghouse Savannah River Company}

Prepared for the U. S. Department of Energy under Contract DE-AC09-96SR18500 
WSRC-TR-98-00238

APPROVALS

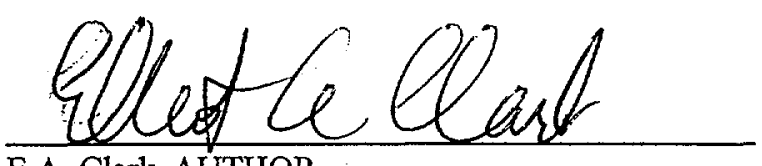

E.A. Clark, AUTHOR

Materials Compatibility and Joining Technology Group MATERIALS TECHNOLOGY SECTION

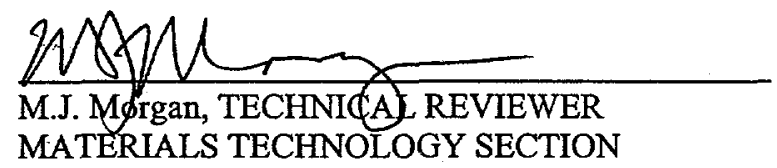

D. Rarm-Raleri

D.T. Rankin, MANAGER

Materials Compatibility and Joining Technology Group MATERIALS TECHNOLOGY SECTION

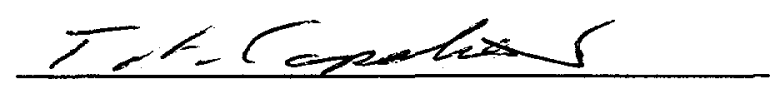

T.L. Capeletti, MANAGER

MATERIALS TECHNOLOGY SECTION

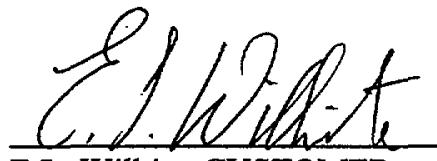

E.L. Wilhite, CUSTOMER

WASTE PROCESSING TECHNOLOGY SECTION
Date: $8 / 10 / 98$

Date: 8110198

Date: $8 / 10 / 98$

Date: $8 / 10 / 98$

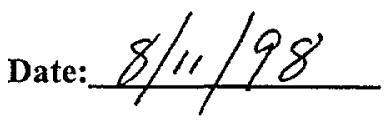

ii 


\section{Contents}

Summary

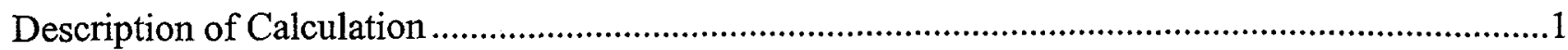

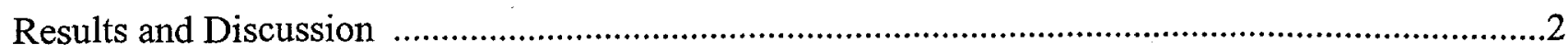

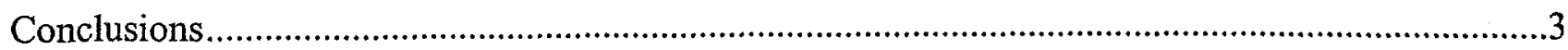

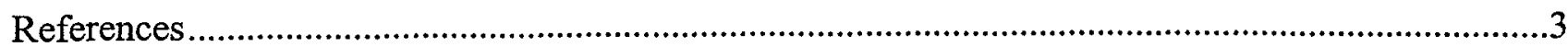

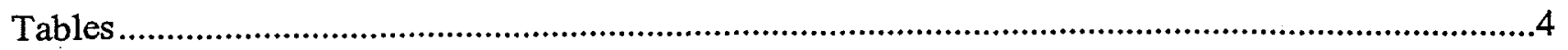

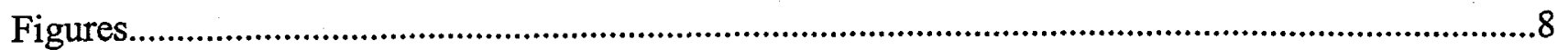

\section{Tables}

I. Input Parameters Used for APT Waste Container Tritium Permeation Calculation ...................4

II. Input Parameters Used for CLWR-TEF Waste Container Tritium Permeation Calculation

III. Spreadsheet Converting Input Values to Quantities and Units For Permeation Estimate - APT Waste Containers ....................................................................................................................5

IV. Spreadsheet Converting Input Values to Quantities and Units For Permeation Estimate CLWR-TEF Overpack Waste Container

V. Summary of Tritium Permeation Calculation Results .7

\section{Figures}

1. Permeation Rate of Tritium out of APT Aluminum Container .................................................8

2. Total Tritium Permeated From Aluminum Container, $100^{\circ} \mathrm{C}$, as a Function of Time...............9

3. Total Tritium Permeating APT Waste, for the Waste Containers Analyzed .................................10 
WSRC-TR-98-00238

THIS PAGE INTENTIONALLY BLANK 
WSRC-TR-98-00238

\section{Tritium Permeation Estimate from APT and TEF-CLWR Waste Packages}

Elliot A. Clark

\section{Summary}

The amount of tritium permeating out of waste containers has been estimated for the Accelerator Production of Tritium project (APT) and for the Commercial Light Water Reactor - Tritium Extraction Facility project (CLWR-TEF). The waste packages analyzed include the Aluminum, Window, Tungsten, Lead, and Steel packages for the APT project, and the overpack of extracted Tritium Producing Burnable Absorber Rods (TPBARs) for the CLWR-TEF project. All of the tritium contained in the waste was assumed to be available as a gas in the free volume inside the waste container at the beginning of disposal, and to then permeate the stainless steel waste container. From estimates of the tritium content of each waste form, the void or free volume of the package, disposal temperature and container geometry, the amount of tritium exiting the waste container by permeation was calculated. Two tritium permeation paths were considered separately: through the entire wall surface area and through the weld area only, the weld area having reduced thickness and significantly less surface area compared to the wall area. Permeation out of the five APT waste containers at $50^{\circ} \mathrm{C}$ is mainly through the welds, and at $100^{\circ} \mathrm{C}$ is through the permeation out of the the entire wall surface area. The largest maximum offgas rate from an APT waste stream at $50^{\circ} \mathrm{C}$ (estimated disposal temperature) was $1.8 \mathrm{E}-6 \mathrm{Ci} / \mathrm{year}$ from the weld of the Window waste package, and the smallest maximum offgas rate was $3.7 \mathrm{E}-5 \mathrm{Ci} /$ year from the weld of the Lead waste package. Permeation from the CLWR-TEF overpack at $40^{\circ} \mathrm{C}$ is mainly through the entire wall surface area, with a maximum offgas rate of $1.3 \mathrm{E}-5 \mathrm{Ci} /$ year.

\section{Description of Calculation}

To help plan waste disposal operations from the Accelerator Production of Tritium project (APT) and the Commercial Light Water Reactor - Tritium Extraction Facility project (CLWR-TEF), the permeation of tritium out of waste containers has been calculated using current estimates for tritium content in the waste, the size and shape of waste containers, and the environmental conditions during disposal. The waste packages analyzed include the Aluminum, Window, Tungsten, Lead, and Steel waste packages for the APT project, and the overpack of extracted Tritium Producing Burnable Absorber Rods (TPBARs) for the CLWR-TEF project. All packages are assumed to be made of one of the 3XX Types of austenitic stainless steel, such as Type 304L or 316L. The five APT containers are rectangular boxes, and the CLWR-TEF container is a right circular cylinder. All containers are assumed to be welded closed after the waste is placed in the container. For all six packages, permeation was analyzed through the entire wall area and separately through the weld area only. The welds were assumed to have reduced thickness compared to the wall - if full penetration welds are used, permeation results for the entire wall area is the appropriate quantity to use. The permeability constants of the weld region were assumed to be the same as for the wall; the only difference between weld and wall is the reduced thickness and lower surface area of the weld. 
An assumption made for this analysis was that all of the tritium contained in the waste in a given package is available as tritium gas in the void space inside the container and outside the waste at the beginning of disposal, when the package is welded shut. The partial pressure of the available tritium gas is calculated from the estimated tritium content of the waste and the void volume estimate, and tritium permeation through the wall is calculated using a finite difference computer program. This assumption leads to a conservative estimate of tritium permeation, since likely much of the tritium will remain in the waste and eventually decay to ${ }^{3} \mathrm{He}$ before it is available for permeation. Lack of knowledge about transport of tritium out of the waste and into the void space forces the use of this conservative assumption.

Some of the assumed values for the APT storage containers (Table I) were provided by the APT project and others were found in the APT Pollution Protection Design Assessment [1]. Assumed values for the CLWR-TEF TPBAR overpack (Table II) were provided by the CLWR-TEF project. The tritium content of the four APT waste types was provided in units of Curies (Ci) per cc of waste, and the estimated void fraction of each container was also provided. Microsoft Excel spreadsheets were used to convert the units of some of these values to those required for the inputs to the finite difference program used to calculate permeability (Tables III, IV). After calculating the container volumes from their dimensions, the volume occupied by waste was found by multiplying the container volume by one minus the void fraction, and then the total tritium content in Curies was calculated by multiplying the volume occupied by waste times the tritium content in $\mathrm{Ci}$ per unit volume. The total tritium content in each package was converted to $\mathrm{cc}$ tritium at Standard Temperature and Pressure (STP, $273 \mathrm{~K}$ and $1 \mathrm{~atm}$ ) by dividing by $2.589 \mathrm{Ci} / \mathrm{cc} \mathrm{T}_{2}$ [2]. The partial pressure of the potentially available tritium in the void space in each container was then calculated using

$$
p=\frac{v^{\text {stdcc }} \cdot T^{v o i d}}{v^{\text {void }} \cdot 273}
$$

where $p$ is the pressure in atmospheres, $v^{\text {stdcc }}$ is the total amount of tritium in the waste in cc tritium at STP, $T^{\text {void }}$ is the temperature $(\mathrm{K})$, and $v^{\text {void }}$ is the void volume (void fraction times container volume). This virtual partial pressure is input to the finite difference permeation program.

The finite difference program [3] calculated the tritium permeation per unit area per unit time from the temperature, tritium partial pressure, wall thickness, exposure time, and material type. The geometrical properties of each container type was used with output from the program to calculate the total Curies permeating out of a given waste container as a function of time. Output of the finite difference program was analyzed and graphed by converting the output to Microsoft Excel spreadsheets. The finite difference program accounts for tritium decay inside the container and inside the wall. The total amount of tritium permeated out of the container was calculated by numerically integrating the permeation rate with time. The total tritium permeated out was not corrected for tritium decay, to be consistent with the further use of results reported here to evaluate waste disposal.

\section{$\underline{\text { Results and Discussion }}$}

The tritium permeation rate from the outside surface increases to a maximum and then returns to zero with time (Figure 1). Integrating this curve results in a typical curve exhibiting increasing total 
permeation until the total is reached (Figure 2). Results of all calculations, including the maximum permeation rate and the total Curies permeated, are presented in Table $\mathrm{V}$ and Figure 3. Permeation through the reduced thickness at welds was the dominant mechanism of tritium release for the five APT packages at $50^{\circ} \mathrm{C}$. For the APT packages at $100^{\circ} \mathrm{C}$ and for the TEF overpack package at $40^{\circ}$ $\mathrm{C}$, permeation though the container walls is much greater than that through the weld, and so determines the tritium offgas rate. Even though the surface area of the weld is much less than that of the walls themselves (by a factor of typically 120 times), the reduced thickness of the weld causes enough increased permeation per unit area for the weld permeation to dominate in the $50^{\circ} \mathrm{C}$ APT packages.

\section{Conclusions}

Tritium permeation from stainless steel packages containing waste from five waste streams from the Accelerator Production of Tritium project and from the Commercial Light Water Reactor - Tritium Extraction Facility project has been calculated from current estimates of properties of each waste stream and the associated packaging. All of the tritium contained in the waste was assumed to be available for permeating the waste container wall. The reduced thickness assumed for welds can cause the weld to account for more permeation than the rest of the wall, depending on temperature.

\section{References}

1. APT Pollution Protection Design Assessment. Report WSRC-TR-97-0260, Westinghouse Savannah River Co., DOE Savannah River Site, Aiken, SC (18 September 1997).

2. DOE Handbook: Primer on Tritium Safe Handling Practices. US Department of Energy Report DOE-HDBK-1079-94 (December 1994).

3. K.E. Kain. Finite-Difference Program for Hydrogen Diffusion. Report DP-1738, E.I. du Pont de Nemours \& Co., Savannah River Laboratory, DOE Savannah River Site, Aiken, SC (March 1987). 


\begin{tabular}{|l|c|c|c|c|c|}
\hline & Aluminum & Window & Tungsten & Lead & Steel \\
\hline Wall Thickness (in) & 0.5 & 0.5 & 0.5 & 0.5 & 0.5 \\
\hline Weld Thickness (in) & 0.25 & 0.25 & 0.25 & 0.25 & 0.25 \\
\hline Weld Width (in) & 0.5 & 0.5 & 0.5 & 0.5 & 0.5 \\
\hline Container Length (ft) & 6 & 12 & 6 & 6 & 6 \\
\hline Container Width (ft) & 4 & 4 & 2 & 4 & 4 \\
\hline Container Height & 4 & 4 & 2 & 2 & 2 \\
\hline $\begin{array}{l}\text { Tritium Content of Waste } \\
\text { after Interim Storage } \\
\text { Period (Ci/cc) }\end{array}$ & 0.116 & 1.357 & 2.590 & 0.147 & 1.357 \\
\hline $\begin{array}{l}\text { Interim Storage Period } \\
\text { (year) }\end{array}$ & 2 & 5 & 5 & 2 & 5 \\
\hline $\begin{array}{l}\text { Temperatures Calculated } \\
\left({ }^{\circ} \text { C) }\right.\end{array}$ & 50,100 & 50,100 & 50,100 & 50,100 & 50,100 \\
\hline
\end{tabular}

Table I. Input Parameters Used for APT Waste Container Tritium Permeation Calculation.

\begin{tabular}{|l|c|}
\hline Wall Thickness (in) & 0.188 \\
\hline Weld Thickness (in) & 0.1225 \\
\hline Weld Width (in) & 0.25 \\
\hline Inside Diameter (ft) & 1.468 \\
\hline Length (ft) & 16 \\
\hline Void volume (cu. ft.) & 12.9 \\
\hline Tritium content per rod (Ci) & 133 \\
\hline Number of Rods per package & 300 \\
\hline Waste Storage Temperature $\left({ }^{\circ} \mathrm{C}\right)$ & 40 \\
\hline
\end{tabular}

Table II. Input Parameters Used for CLWR-TEF Waste Container Tritium Permeation Calculation. 


\begin{tabular}{|c|c|c|c|c|c|c|c|c|c|c|}
\hline Container Wall thickness (in) & 0.50 & & & & & & & & & \\
\hline Minimum weld thickness (in) & 0.25 & & & & & & & & & \\
\hline Weld width (in) & 0.50 & 1.27 & & & & & & & & \\
\hline Waste Type & \multicolumn{2}{|c|}{ Aluminum } & \multicolumn{2}{|c|}{ Window } & \multicolumn{2}{|c|}{ Tungsten } & \multicolumn{2}{|r|}{ Lead } & \multicolumn{2}{|r|}{ Steel } \\
\hline Container Dimensions: & $\mathrm{Ft}$ & $\mathrm{cm}$ & $\mathrm{Ft}$ & $\mathrm{cm}$ & $\mathrm{Ft}$ & $\mathrm{cm}$ & Ft & $\mathrm{cm}$ & Ft & $\mathrm{cm}$ \\
\hline Length & 6 & 182.88 & 12 & 365.76 & 6 & 182.88 & 6 & 182.88 & 6 & 182.88 \\
\hline Width & 4 & 121.92 & 4 & 121.92 & 2 & 60.96 & 4 & 121.92 & 4 & 121.92 \\
\hline Height & 4 & 121.92 & 4 & 121.92 & 2 & 60.96 & 2 & 60.96 & 2 & 60.96 \\
\hline Volume (cc) & & $2.72 \mathrm{E}+06$ & & $5.44 \mathrm{E}+06$ & & $6.80 \mathrm{E}+05$ & & $1.36 \mathrm{E}+06$ & & $1.36 \mathrm{E}+06$ \\
\hline Container Surface Area $(\mathrm{cm} 2)$ & & 118,916 & & 208,103 & & 52,026 & & 81,755 & & 81,755 \\
\hline Weld Surface Area $(\mathrm{cm} 2)$ & & 774 & & 1,239 & & 619 & & 774 & & 774 \\
\hline & & & & & & & & & & \\
\hline \multicolumn{2}{|l|}{$\begin{array}{l}\text { Tritium Content of Waste } \\
(\mathrm{Ci} / \mathrm{cc}) \text { after interim storage period }\end{array}$} & 0.116 & & 1.357 & & 2.590 & & 0.147 & & $\mathbf{1 . 3 5 7}$ \\
\hline & & & & & & & & & & \\
\hline Void Volume Fraction & & $40 \%$ & & $50 \%$ & & $70 \%$ & & $50 \%$ & & $50 \%$ \\
\hline & & & & & & & & & & \\
\hline Total Tritium / Container (Ci) & & $1.88 \mathrm{E}+05$ & & $3.69 \mathrm{E}+06$ & & $5.28 \mathrm{E}+05$ & & $9.99 \mathrm{E}+04$ & & $9.22 \mathrm{E}+05$ \\
\hline Total Tritium / Container (cc STP) & & $7.28 \mathrm{E}+04$ & & $1.43 \mathrm{E}+06$ & & $2.04 \mathrm{E}+05$ & & $3.86 \mathrm{E}+04$ & & $3.56 \mathrm{E}+05$ \\
\hline & & & & & & & & & & \\
\hline Temperature $\left({ }^{\circ} \mathrm{C}\right)$ & & 50 & & 50 & & 50 & & 50 & & 50 \\
\hline $\begin{array}{l}\text { Virtual Tritium Partial } \\
\text { Pressure @ start (atm) }\end{array}$ & & 0.079 & & 0.620 & & 0.507 & & 0.067 & & 0.620 \\
\hline
\end{tabular}

Table III. Spreadsheet Converting Input Values to Quantities and Units For Permeation Estimate APT Waste Containers.

Note: Bold quantities are input assumptions, other quantities are calculated from the assumptions. 


\begin{tabular}{|c|c|c|c|c|c|}
\hline \multicolumn{6}{|l|}{18 " Schedule 10S pipe } \\
\hline $\begin{array}{l}\text { Container Wall } \\
\text { thickness (in) }\end{array}$ & 0.188 & & & & \\
\hline $\begin{array}{l}\text { Minimum Weld } \\
\text { Thickness (in) }\end{array}$ & 0.125 & Weld Width (inch) & 0.25 & $\begin{array}{l}\text { Weld Surface Area } \\
(\mathrm{cm} 2)\end{array}$ & 91.17 \\
\hline $\begin{array}{l}\text { Container Inside } \\
\text { Diameter }(\mathrm{ft})\end{array}$ & 1.468 & \begin{tabular}{|l|}
$\begin{array}{l}\text { Container Outside } \\
\text { Diameter }(\mathrm{cm})\end{array}$ \\
\end{tabular} & 45.7 & & \\
\hline Length (ft) & 16 & Length $(\mathrm{cm})$ & 487.7 & $\begin{array}{l}\text { Container Outside } \\
\text { Surface Area }(\mathrm{cm} 2)\end{array}$ & 70,016 \\
\hline Void Volume (cu. $\mathrm{ft}$ ) & 12.9 & Void Volume (cc) & 365,287 & & \\
\hline $\begin{array}{l}\text { Tritium Content per } \\
\text { Rod }(\mathrm{Ci})\end{array}$ & 133 & Number of Rods & 300 & $\begin{array}{l}\text { Tritium Content of } \\
\text { Waste (Ci) }\end{array}$ & 39,900 \\
\hline & & & & $(\mathrm{Std} c \mathrm{~T} 2)$ & 15,411 \\
\hline Temperature $\left({ }^{\circ} \mathrm{C}\right)$ & 40 & & & & \\
\hline & & & & $\begin{array}{l}\text { T2 Partia1 Pressure @ } \\
\text { start (atm) }\end{array}$ & 0.0484 \\
\hline
\end{tabular}

Table IV. Spreadsheet Converting Input Values to Quantities and Units For Permeation Estimate CLWR-TEF Overpack Waste Container.

Note: Bold quantities are input assumptions, other quantities are calculated from the assumptions. 


\begin{tabular}{|c|c|c|c|c|c|c|c|}
\hline Container \& Path & $\frac{\text { Thickness }}{\text { (inch) }}$ & $\frac{\text { Temperature }}{\left({ }^{\circ} \mathrm{C}\right)}$ & $\frac{\text { Surface }}{\text { Area }}$ & $\frac{\underline{\text { Maximum }}}{\frac{\text { Permeation }}{\underline{\text { Rate }}}}$ & $\frac{\underline{\text { Total }}}{\text { Tritium }}$ & $\begin{array}{c}\frac{\text { Maximum }}{\text { Annual }} \\
\text { Offgas Rate } \\
\text { (Ci/year) }\end{array}$ & \begin{tabular}{|c|}
$\frac{\text { Time to }}{\text { Maximum }}$ \\
Offgas Rate \\
(year)
\end{tabular} \\
\hline $\begin{array}{l}\text { TEF Overpack } \\
\text { Container }\end{array}$ & 0.188 & 40 & 70,016 & $2.3 \mathrm{E}-18$ & $1.3 \mathrm{E}-03$ & $1.3 \mathrm{E}-05$ & 115 \\
\hline TEF Overpack Weld & 0.125 & 40 & 91 & $1.8 \mathrm{E}-16$ & $1.1 \mathrm{E}-04$ & $1.3 \mathrm{E}-06$ & 80 \\
\hline Aluminum Container & 0.5 & 50 & 118,916 & $6.0 \mathrm{E}-23$ & 7.7E-08 & $5.8 \mathrm{E}-10$ & 195 \\
\hline Aluminum Weld & 0.25 & 50 & 774 & $6.4 \mathrm{E}-18$ & $4.0 \mathrm{E}-05$ & $4.1 \mathrm{E}-07$ & 113 \\
\hline Lead Container & 0.5 & 50 & 81,755 & $5.5 \mathrm{E}-23$ & $4.9 \mathrm{E}-08$ & $3.7 \mathrm{E}-10$ & 195 \\
\hline Lead Weld & 0.25 & 50 & 774 & $5.9 \mathrm{E}-18$ & $3.7 \mathrm{E}-05$ & $3.7 \mathrm{E}-07$ & 113 \\
\hline Tungsten Container & 0.5 & 50 & 52,026 & $1.5 \mathrm{E}-22$ & $8.5 \mathrm{E}-08$ & $6.4 \mathrm{E}-10$ & 195 \\
\hline Tungsten Weld & 0.25 & 50 & 619 & $1.6 \mathrm{E}-17$ & $8.2 \mathrm{E}-05$ & $8.2 \mathrm{E}-07$ & 113 \\
\hline Window Container & 0.5 & 50 & 208,103 & $1.7 \mathrm{E}-22$ & $3.8 \mathrm{E}-07$ & $2.8 \mathrm{E}-09$ & 195 \\
\hline Window Weld & 0.25 & 50 & 1,239 & $1.8 \mathrm{E}-17$ & $1.8 \mathrm{E}-04$ & $1.8 \mathrm{E}-06$ & 113 \\
\hline Steel Container & 0.5 & 50 & 81,755 & $1.7 \mathrm{E}-22$ & $1.5 \mathrm{E}-07$ & $1.1 \mathrm{E}-09$ & 195 \\
\hline Steel Weld & 0.25 & 50 & 774 & $1.8 \mathrm{E}-17$ & $1.1 \mathrm{E}-04$ & $1.1 \mathrm{E}-06$ & 113 \\
\hline Aluminum Container & 0.5 & 100 & 118,916 & $1.4 \mathrm{E}-14$ & $1.1 \mathrm{E}+01$ & $1.4 \mathrm{E}-01$ & 60 \\
\hline Aluminum Weld & 0.25 & 100 & 774 & $5.2 \mathrm{E}-13$ & $2.0 \mathrm{E}+00$ & $3.3 \mathrm{E}-02$ & 30 \\
\hline Lead Container & 0.5 & 100 & 81,755 & $1.3 \mathrm{E}-14$ & $6.9 \mathrm{E}+00$ & $8.8 \mathrm{E}-02$ & 60 \\
\hline Lead Weld & 0.25 & 100 & 774 & $4.8 \mathrm{E}-13$ & $1.8 \mathrm{E}+00$ & $3.1 \mathrm{E}-02$ & 30 \\
\hline Tungsten Container & 0.5 & 100 & 52,026 & $3.6 \mathrm{E}-14$ & $1.2 \mathrm{E}+01$ & $1.5 \mathrm{E}-01$ & 60 \\
\hline Tungsten Weld & 0.25 & 100 & 619 & $1.3 \mathrm{E}-12$ & $4.0 \mathrm{E}+00$ & $6.7 \mathrm{E}-02$ & 30 \\
\hline Window Container & 0.5 & 100 & 208,103 & $4.0 \mathrm{E}-14$ & $5.3 \mathrm{E}+01$ & $6.8 \mathrm{E}-01$ & 60 \\
\hline Window Weld & 0.25 & 100 & 1,239 & $1.5 \mathrm{E}-12$ & $8.9 \mathrm{E}+00$ & $1.5 \mathrm{E}-01$ & 30 \\
\hline Steel Container & 0.5 & 100 & 81,755 & $4.0 \mathrm{E}-14$ & $2.1 \mathrm{E}+01$ & $2.7 \mathrm{E}-01$ & 60 \\
\hline Steel Weld & 0.25 & 100 & 774 & $1.5 \mathrm{E}-12$ & $5.6 \mathrm{E}+00$ & $9.3 \mathrm{E}-02$ & 30 \\
\hline
\end{tabular}

Table V. Tritium Permeation Calculation Results.

Note: Two container/paths labeled TEF refer to the Commercial Light Water Reactor - Tritium Extraction Facility project, all others are for the Accelerator Production of Tritium Project (APT). The estimated temperature in the disposal environment for the APT containers is $50^{\circ} \mathrm{C}$, the $100^{\circ} \mathrm{C}$ calculations were performed to investigate the sensitivity of permeation to temperature. 
WSRC-TR-98-00238

Aluminum $50 \mathrm{C}$

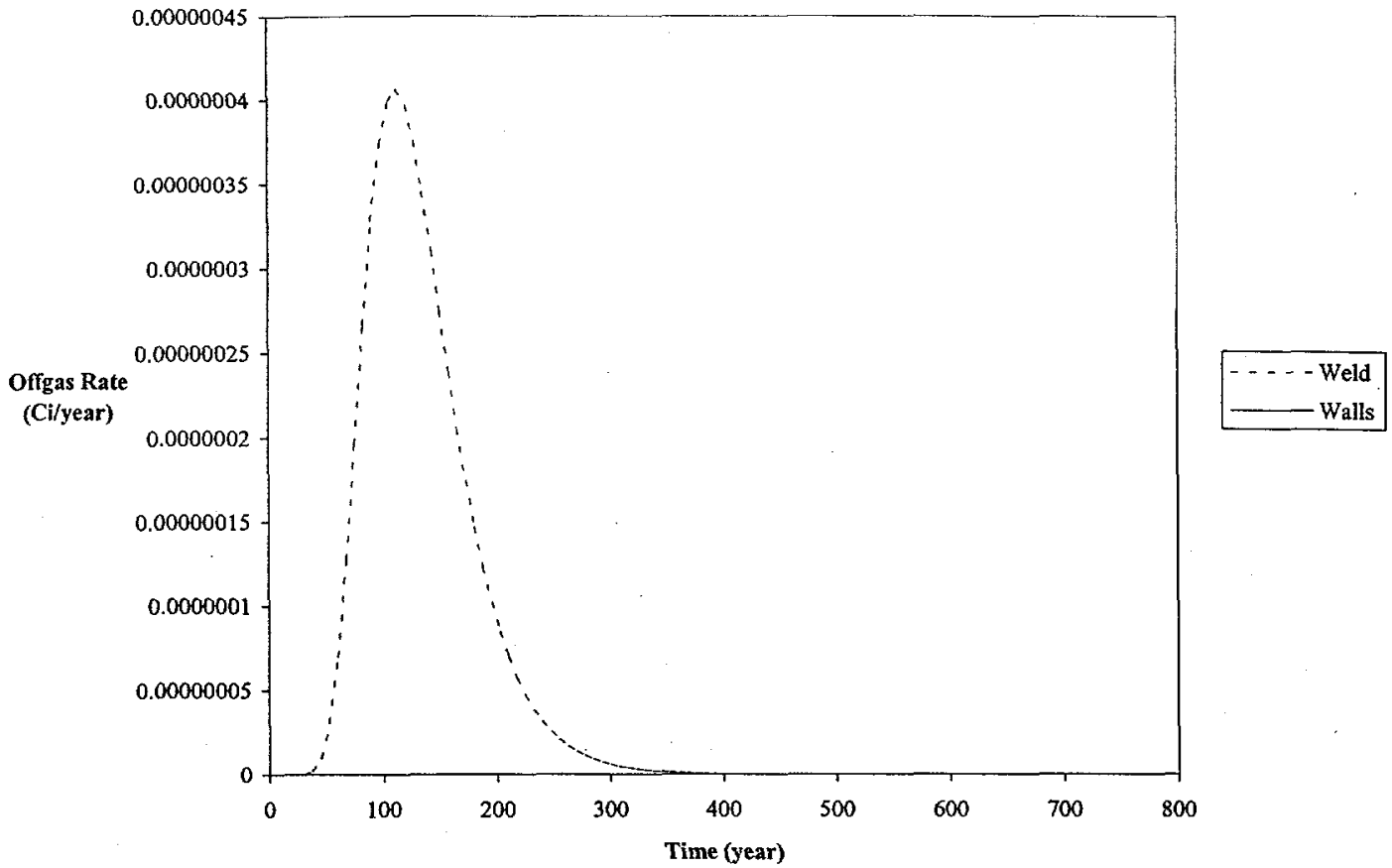

Aluminum $100 \mathrm{C}$

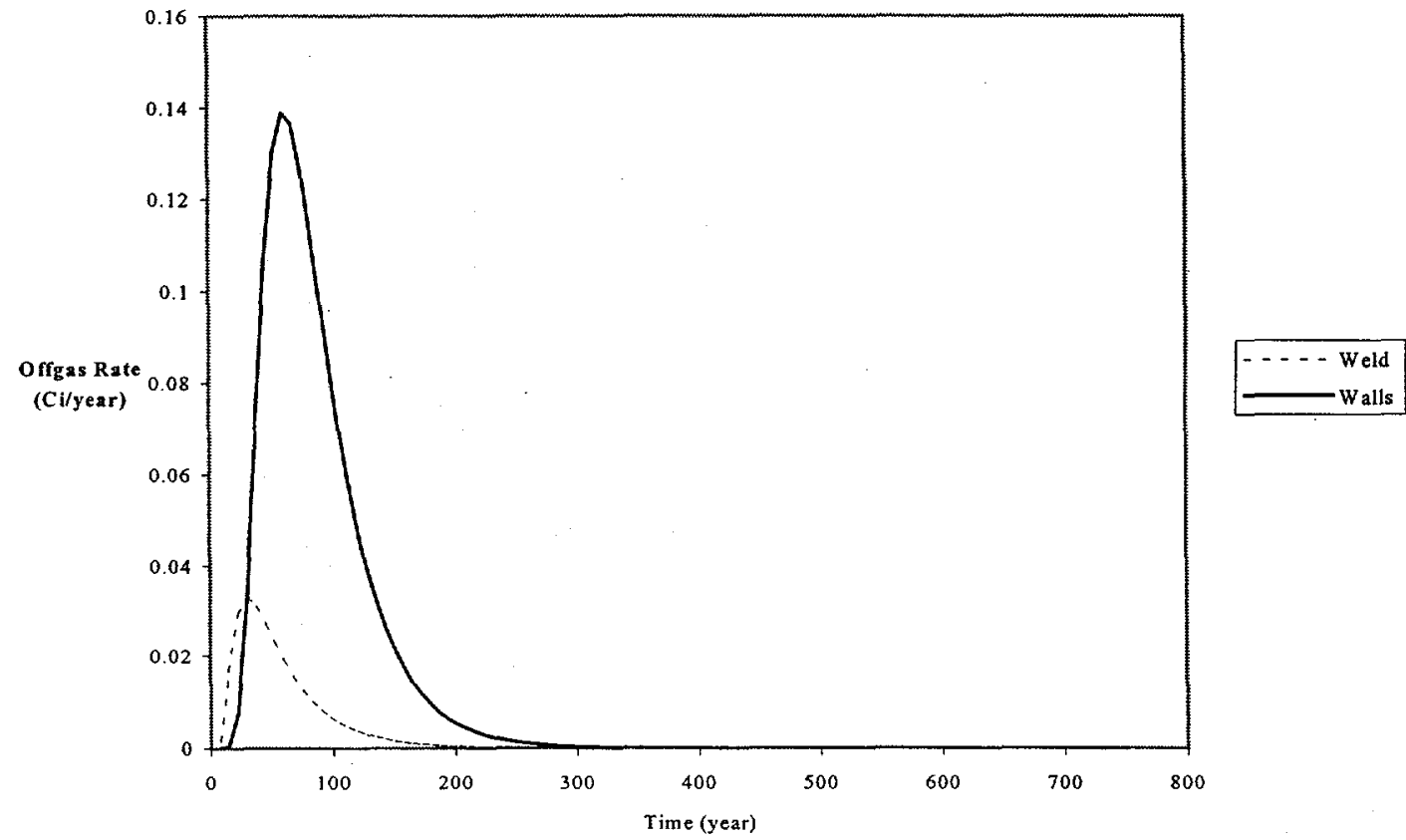

Figure 1. Permeation rate of tritium out of APT Aluminum container, at $50^{\circ} \mathrm{C}$ (top) and $100^{\circ} \mathrm{C}$ (bottom). Weld permeation much greater than through walls at $50^{\circ} \mathrm{C}$, wall data too small to be visible on graph. Note walls provide most permeation at $100^{\circ} \mathrm{C}$. Other containers exhibit similar behavior. See also Table V for maximum permeation rates, times. Graphs typical of those for all container types. 
WSRC-TR-98-00238

Aluminum Container $100 \mathrm{C}$

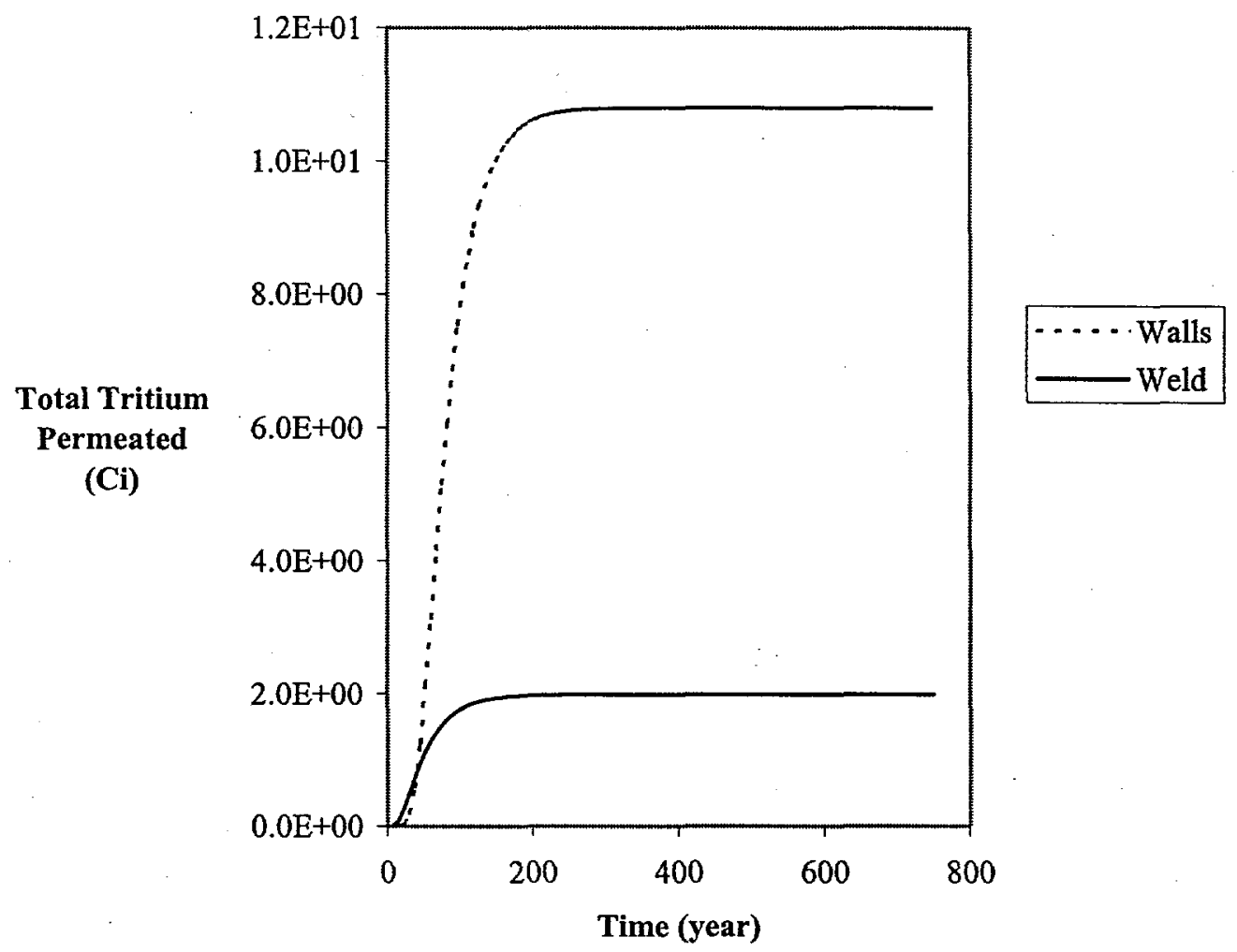

Figure 2. Total Tritium Permeated from Aluminum Container, $100^{\circ} \mathrm{C}$, as a function of Time. Note that tritium permeates the weld first, but most tritium comes from the walls. Graph typical of all container types. 




Figure 3. Total Tritium Permeating APT Waste, for the different waste containers analyzed. Note welds permeate more at $50^{\circ} \mathrm{C}$ and walls more at $100^{\circ} \mathrm{C}$, comparing like waste streams. 
WSRC-TR-98-00238

THIS PAGE INTENTIONALLY BLANK 


\section{Distribution for WSRC-TR-98-00238}

\begin{tabular}{|l|l|l|l|}
\hline E.L. Wilhite & $773-43 \mathrm{~A}$ & S.L.West & $773-\mathrm{A}$ \\
\hline J.R. Cook & $773-43 \mathrm{~A}$ & D.T. Rankin & $773-\mathrm{A}$ \\
\hline B.T. Butcher & $773-43 \mathrm{~A}$ & M.J. Morgan & $773-\mathrm{A}$ \\
\hline W.E. Stevens & $773-\mathrm{A}$ & T.L. Capeletti & $773-41 \mathrm{~A}$ \\
\hline W.T. Goldston & $705-3 \mathrm{C}$ & T. Motyka & $773-\mathrm{A}$ \\
\hline M.J. Ades & $705-3 \mathrm{C}$ & J.R. Knight & $773-\mathrm{A}$ \\
\hline D.F Sink & $724-15 \mathrm{E}$ & N.C. Iyer & $773-\mathrm{A}$ \\
\hline R.W. Reynolds & $703-45 \mathrm{~A}$ & B.C. Rogers & $773-42 \mathrm{~A}$ \\
\hline J.S. Roberts & $703-45 \mathrm{~A}$ & MTS Files & $773-\mathrm{A}$ \\
\hline J.L. England & $\begin{array}{l}\text { Los Alamos National } \\
\text { Laboratory }\end{array}$ & $\begin{array}{l}\text { Scientific and Technical } \\
\text { Information (4 copies) }\end{array}$ & 703-43A \\
\hline S.O. Sheetz & $\begin{array}{l}\text { Los Alamos National } \\
\text { Laboratory }\end{array}$ & & \\
\hline
\end{tabular}

